\title{
Anti-salt dam as a means of recovering lowland degraded by sea water: the case of lowland Ndour Ndour, Senegal
}

\author{
Bama Nati Aïssata Delphine ${ }^{1,2}$, Bado Boubié Vincent ${ }^{3}$, Soussou Sambou $^{4}$, Mel Valère ${ }^{3}$, Gaye \\ Cheikh Becaye ${ }^{1}$ \\ ${ }^{1}$ Laboratoire d'hydrogéologie, Université Cheikh Anta Diop, Dakar, Sénégal BP 5005 Dakar-fann \\ ${ }^{2}$ Institut de l'Environnement et de Recherche Agricole (INERA), Ouagadougou, Burkina Faso \\ ${ }^{3}$ Station Régionale du Sahel, Centre du riz pour l'Afrique (AfricaRice), BP 96Saint Louis, Sénégal \\ ${ }^{4}$ Laboratoire d'Hydraulique et de Mécanique des Fluides, Université Cheikh Anta Diop, Dakar, Sénégal. BP 5005 Dakar-fann
}

\section{Email address:}

nati_aissata@yahoo.fr(B. N. A. Dephine)

\section{To cite this article:}

Bama Nati Aïssata Delphine, Bado Boubié Vincent,Soussou Sambou, Mel Valère, Gaye Cheikh Becaye. Anti-Salt Dam as a Means of Recovering Lowland Degraded by Sea Water: the Case of Lowland Ndour Ndour, Senegal. American Journal of Environmental Protection. Vol. 2, No. 3, 2013, pp. 79-84. doi: 10.11648/j.ajep.20130203.11

\begin{abstract}
The reduction of the quantity of water that flows in the lowlands of Sine Saloun, toward the ocean, has favored saltwater intrusion. To fight against, anti-salt dikes were built. This study aimed to analyze: (1) the rainfall over the last years, in the region, in order to determine its variability likely to impact outcropping of salt. (2) The impact of the anti-salt dam on the protection and recovery of the salt lands. The level of the groundwater, standing water and salinity were monitored, during two wet seasons. The break occurred in 1967 and from this time, the rainfall started declining. The antisalt dam slowed the progress of the seawater into the lowlands by maintaining a certain level of fresh water upstream. The most important determinant for agricultural redevelopment, in these degraded lands, is the amount of water that passes through.
\end{abstract}

Keywords: Rainfall Series, Salt, Dike, Lowland

\section{Introduction}

The potential in term of the lowlands in tropical Africa is estimated at 130 millions hectares, of which 19 millions i.e $15 \%$ are in West Africa[1]. The lowlands are of such a great importance in term of agricultural and hydrological local and national asset, and can contribute significantly to food security and poverty reduction[2]. However, most of these lowlands are threatened by the effects of climate change. Indeed, Africa is becoming the most exposed area in the world to the impacts of climate change. In SubSaharan Africa, extreme weather will make dry areas become drier and wet areas become wetter[3]. These low rainfalls reduced the volume of fresh water that drains from the watershed into rivers and thus salt water from the ocean intrudes much farther inland inundating crop fields and subjecting them to salt stress[4]. These lowlands salinization are expected to be aggravated by increases in sea level nowadays[4]. Added to this is the rapid runoff. We can no more get a big front of water able to push the salt water long enough and far enough to the sea, as the freshwater in the past century. It therefore follows a very rapid progress of salt water, after the rain, on the surface and at depth. The invasion of fresh water by salt water will cause soil degradation and salinization[5].

This is the case in the region of Sine Saloun Senegal, where different studies have shown that salinity is a major environmental problem people are facing there. Indeed, all these lowlands are in direct contact with an inlet[6] favoring the entry of salt water into farmland[7]. The extents of degradation are such as more than a third of the area, in the region, is affected[7]. The decline of the traditional rainfed agriculture was more severe in these areas, currently known as "Le bassin arachidier". As a result of this, many farmers migrated[8].

To overcome this land salinization and allow the recovery of these abandoned areas, several actions have been taken including anti-salt dam.

The objectives of this study were therefore (1) to analyze the rainfall over the last 90 years to highlight its variability, inter and intra annual trend likely to promote seawater 
intrusion. (2) To highlight the impact of the anti-salt dam on the protection and recovery of these salty lowlands for agricultural production.

\section{Material and Method}

\subsection{Presentation of the Study Area}

The total area of the lowland of Ndour Ndour is 134 ha, 60 ha affected by salt, 35 hectares threatened by salt and 39 ha of good valuable soils in front end of the Valley[7]. It is divided into several zones, for rice, forestry, grazing, salt mining, the route of livestock and protection of sensitive areas. The soils are generally sandy, sandy-silty or claysilty, acidic or weakly acidic[9]. Evaporation is very important, around $2950 \mathrm{~mm} /$ year. The climate of this area is Sudano-Sahelian, characterized by the alternation of two seasons: a dry season of eight months, from mid-October to mid-June, with a cool period from November to January and a rainy season of four months, from mid-June to midOctober. The area has an average rainfall of $588.1 \mathrm{~mm}$. The average monthly temperatures varies from $24^{\circ} \mathrm{C}$ (in January) to $31^{\circ} \mathrm{C}$ (May). Three wind streams are important in the region: the maritime tradewind, the continental winds (Harmattan) and Monsoons.

\subsection{Statistical Analysis of Rainfall Series}

Rainfall data collected at the lowland of Ndour Ndour is a series of 34 years (1979-2011). The second station is the weather station of Kaolack, located at $50 \mathrm{~km}$ from the lowland of Ndour Ndour. The serie from this station is longer: 88 years (1918 to 2010). We used the software Khronostat from IRD, for statistical analysis. The analysis of the randomness of time series is based on the analysis of the range correlation test. Detection of break in the series of rainfall data is based on the Pettitt test, the $U$ statistic Buishand, the Bayesian procedure of Lee and Heghiniane. The Pettitt test[10], which is a non-parametric method, is used to identify a change-point in a time series and can be briefly described as follows: Once the change point is detected through the test, then the dataset is divided into two sub-samples. The values of the two samples are grouped and arranged by increasing order. The sum of the ranks of the components of each sub-sample in the total sample is then calculated. The two samples $\left(\mathrm{x}_{1}, \mathrm{x}_{2}, \ldots \mathrm{x}_{\mathrm{t}}\right)$ and $\left(\mathrm{x}_{\mathrm{t}+1}, \mathrm{x}_{\mathrm{t}+2}+2, \ldots, \mathrm{x}_{\mathrm{T}}\right)$ come from the same population. The test statistic $\mathrm{U}_{\mathrm{t}, \mathrm{T}}$ is given by:

$$
\mathrm{U}_{\mathrm{t}, \mathrm{T}}=\Sigma \Sigma \operatorname{sgn}\left(\mathrm{x}_{\mathrm{t}}-\mathrm{x}_{\mathrm{j}}\right)
$$

Where:

$$
\begin{aligned}
& \operatorname{sgn}(x)=1, \text { if } x>0 ; \\
& \operatorname{sgn}(x)=0, \text { if } x=0 \\
& \text { and } \operatorname{sgn}(x)=-1 \text { if } x<0 .
\end{aligned}
$$

The most significant change-point is found where the value $\left|U_{t, T}\right|$ is $\max : K_{T}=\max \left|U_{t, T}\right|$. Assume $k$ is the value of $K_{T}$, under the null hypothesis (no break point), then:

$$
\text { Probability }\left(\mathrm{K}_{\mathrm{T}}>\mathrm{k}\right) \approx 2 \exp \left(\left(-6 \mathrm{k}^{2}\right) /\left(\mathrm{T}^{3}+\mathrm{T}^{2}\right)\right)
$$

If probability $\left(\mathrm{K}_{\mathrm{T}}>\mathrm{k}\right)<\alpha$, for a significance level $\alpha$ (i.e $\alpha=0.01$ ), then the null hypothesis is rejected.

The Buishand[11], Lee and Heghinian tests[12] are Bayesian procedures applied under the assumption that the studied series is normally distributed. The tests are based on the following model:

$$
\begin{gathered}
X_{i}=\mu+\varepsilon_{i}, i=1, t \\
X_{i}=\mu+\varepsilon_{i}+\varepsilon, i=t+1, T
\end{gathered}
$$

where $\varepsilon_{i}$ are random variables, independent and normally distributed, with null expectance and a constant variance. The break point $t$ and the parameters $\mu$ and $\varepsilon$ are known.

The Lee and Heghinian method works in the hypothesis that $\left(\mathrm{X}_{\mathrm{i}}\right)_{\mathrm{i}=1, \mathrm{~T}}$ is a series of independent variables, with a constant variance. The method determines the a posteriori probability distribution function of the parameters $\mu$ and $\varepsilon$, considering their a priori distributions and supposing that the break time follows a uniform distribution. The range of the break time corresponds to the values of the modes of the a posteriori distributions of $\mathrm{t}$ and $\varepsilon$ respectively.

\subsection{Piezometry: Monitoring the Changes in the Level of Groundwater and Salinity}

The dynamics of groundwater was followed during two wet seasons (2010 and 2011) using a series of piezometers installed in the lowland. Surveys of groundwater level have been performed once every week. And water samples were collected from monitoring wells periodically, in order to monitor the electrical conductivity (salinity) level.

\section{Result and Discussion}

\subsection{Variability and Rainfall Pattern in the Region of Sine Saloun}

The correlation test on the range performed on the rainfall series of Kaolack shows a trend effect between successive values. It is concluded that the rainfall in the last 90 years in the region is devoid of randomness. So we used the methods of the U statistic of Buishand, Pettitt test and the Bayesian method of Lee and Heghinian to highlight these trends and breaks. These methods have already been used by[13] in Senegal to analyze rainfall data in the region of the River Senegal. The result of the test of Buishand (Figure 1) highlights the presence of a break in the series of rainfall. This break occurred in the period between 1966 and 1973. The average before the break is $806.45 \mathrm{~mm}$ while it is $572.58 \mathrm{~mm}$ after the break i.e a deficit of $28.99 \%$. 


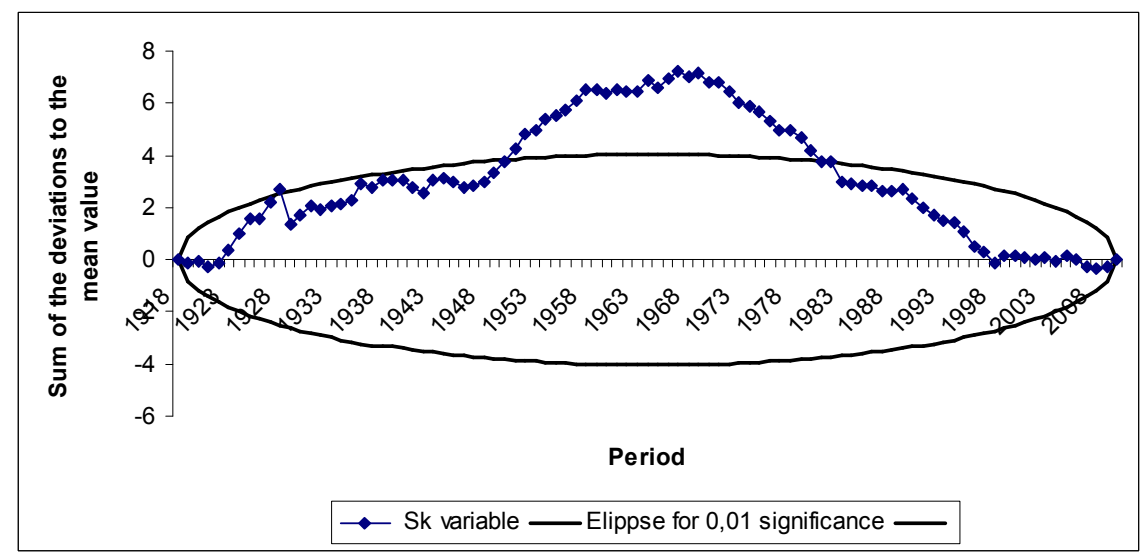

Figure 1. Bois ellipse on annual rainfall from 1919 to 2010 in the Sine Saloun area.

Within a time windows of $\mathrm{T}=88$ years, from 1919 to 2010 , the $U$ function of Pettit reached its maximum value $\left(\mathrm{U}_{\max }=1337\right)$ in the year 1967 (Figure 2). The probability of exceeding the critical value by Pettit test is 2.42 E-6. The null hypothesis is then rejected. In other words, a significant change point exists. For this particular year 1967, the density of probability by using the procedure of Lee and Heghinian is 0.2246 (Figure 2). The breaking point was the year 1967. These analyzes support the results of $[13,14,15]$, which have located most of the ruptures between the end of the 1960s and early 1970s in West and Central Africa.

The figure 3 and 4 show an interannual variability in rainfall, but it is going down at the lowland Ndour Ndour over time.

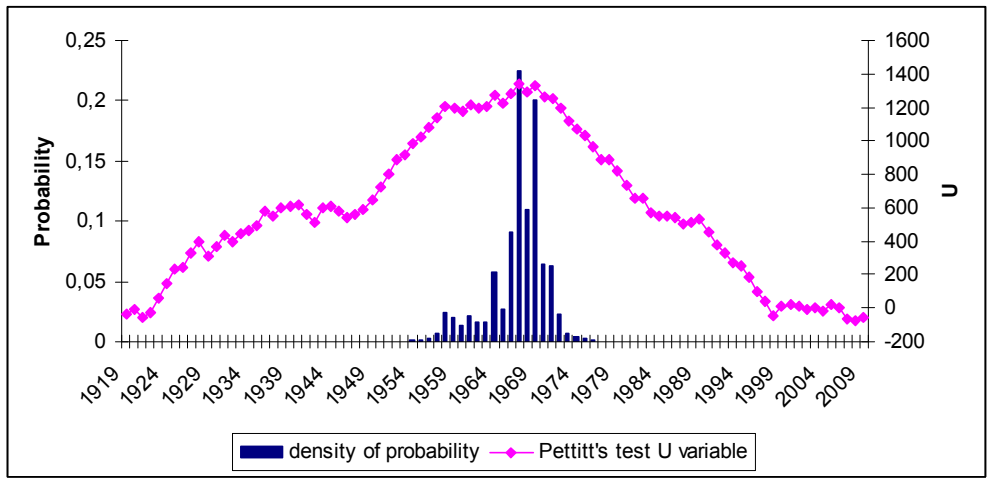

Figure 2. Result of the procedure of Lee and Heghinian, and Pettit's test on annual rainfall from 1919 to 2010 in the Sine Saloun area

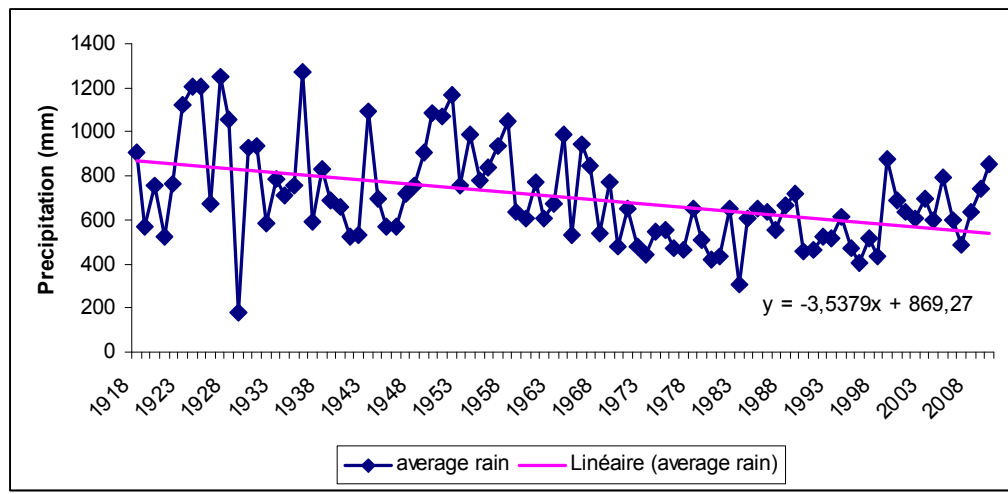

Figure 3. Evolution of the annual mean precipitation over 88 years(1918-2010) in Sine Saloun area. 


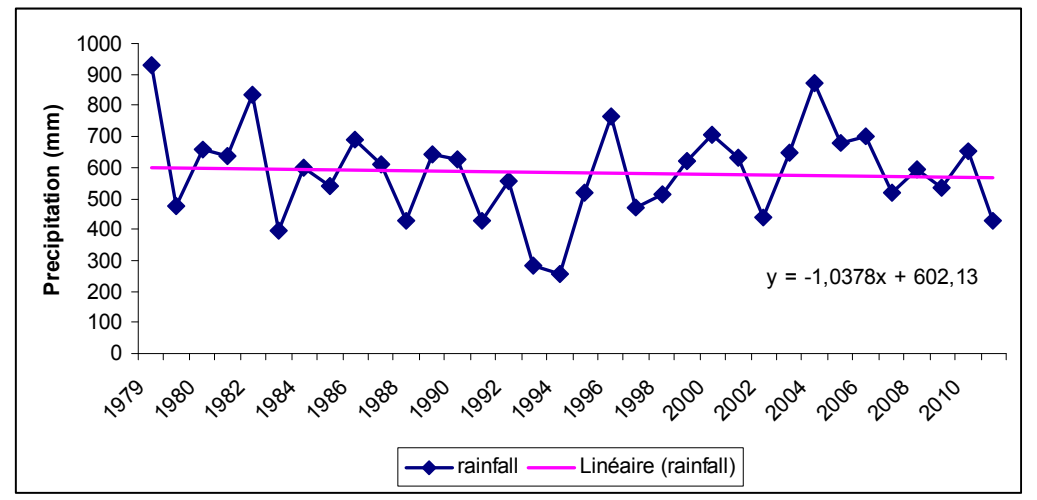

Figure 4. Evolution of the annual mean precipitation over 33 years (1979-2011) in lowland of Ndour Ndour

\subsection{Intra-annual Variability of Rainfall and Its Effect on Salinity: Uncertainty in Agricultural Production in the Lowland Ndour Ndour}

Not only the annual average rainfall is declining in the region of Sine Saloun, also the distribution per month of the annual total rainfall is varying from one year to another. This makes uncertain the strictly rainfed agriculture in these lowlandsThis is confirmed by[14] in the Sine Saloun, with the data of Fatik station which have a decreasing trend. Figure 5 shows the monthly rainfall during the wet season in 2010 and 2011. The year 2011 is in a significant deficit compared to 2010 . This is reflected in a very good rice yield in 2010 averaged $2.65 \mathrm{t} /$ ha in the lowland compared to 2011. Indeed, the plants have not reached maturity in 2011, due to the drought of the end of the cycle, despite the presence of the dam for water retention. To overcome these climate risks, a good management of water at the dam is paramount. These dams should also allow the leaching of salt accumulated during the dry season. We find that the rains received from June to mid-August were insufficient to reduce the level of salt uniformly (Figure 6) under a tolerable threshold for most of the varieties. Indeed, crops like rice begin to feel the salt stress starting from salinity higher than $3 \mathrm{dS} / \mathrm{m}$.

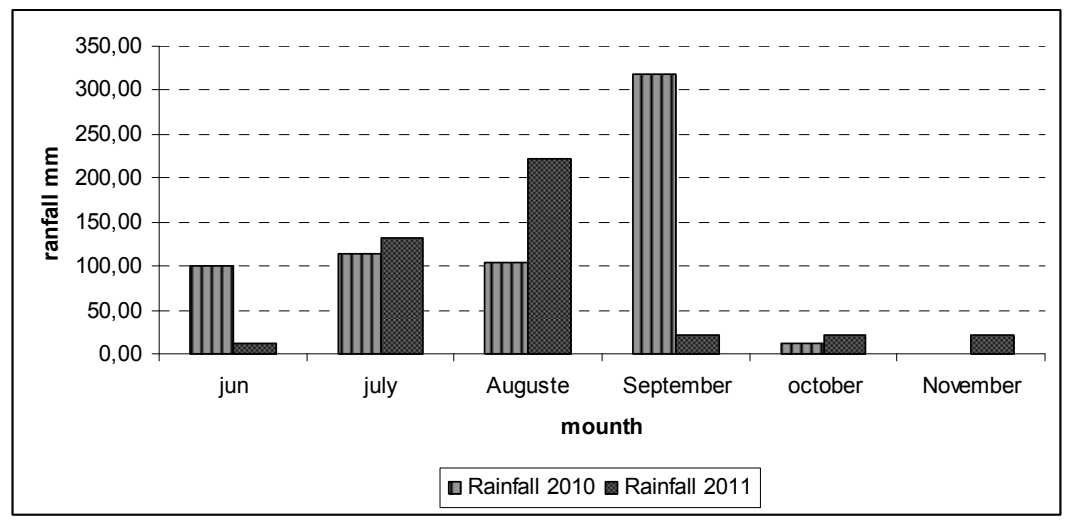

Figure 5. Changes in average monthly rainfall during the wet season in 2010 and 2011

The groundwater recharge is strongly correlated with the amount of rain and especially the height and duration of the standing water retained upstream of the anti-salt dam (Figure 6).[5]led to the same conclusion in 2003 in the lowland. Good rainfall in the early rainy season in 2010 (Figure 5) has performed a rapid leaching of salt in the lowland leading to a tolerable level (less than $2 \mathrm{dS} / \mathrm{m}$ ) before cultivation. In addition, the presence of the standing water layer in the lowland until early October (Figure 6) has maintained a fairly stable level of salinity during the growing period in 2010 compared to 2011, when the standing water was almost non-existent (Figure 7). This lack of standing water, in 2011, in the lowland, is mainly due to the fact that when the salinity reaches a critical level upstream, the water must be drained out in order to evacuate salt. This lack of water in the lowland, combined with sporadic drought during the wet season, imply capillarity rise of salt water from the groundwater and outcrop of the salt in the lowland, after evaporation. This high level of salt in the lowland throughout the wet season in 2011 (Figure 7) is a direct consequence of its low and heterogeneous rainfall (Figure 5). 


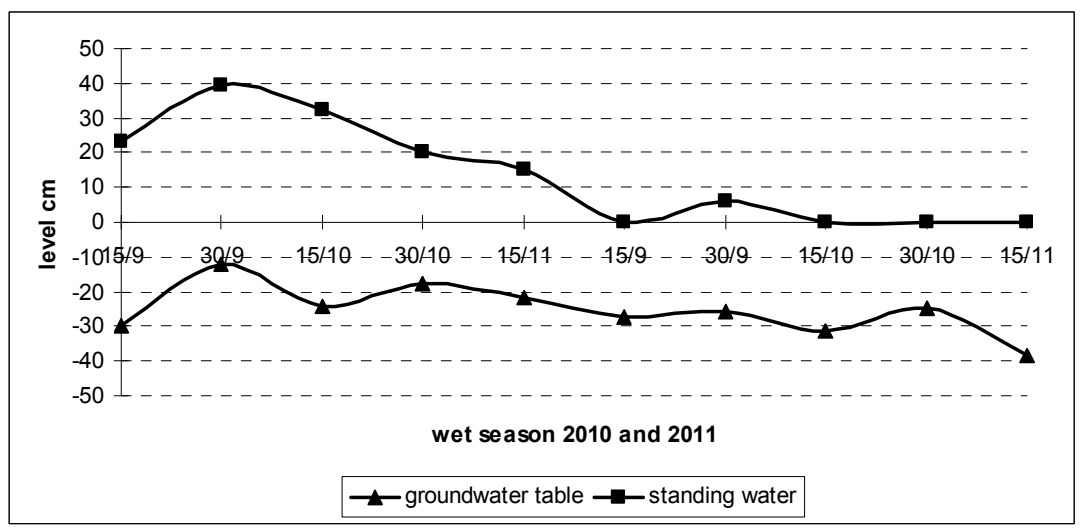

Figure 6. Evolution of groundwater table and standing water level during the wet season 2010 and 2011.

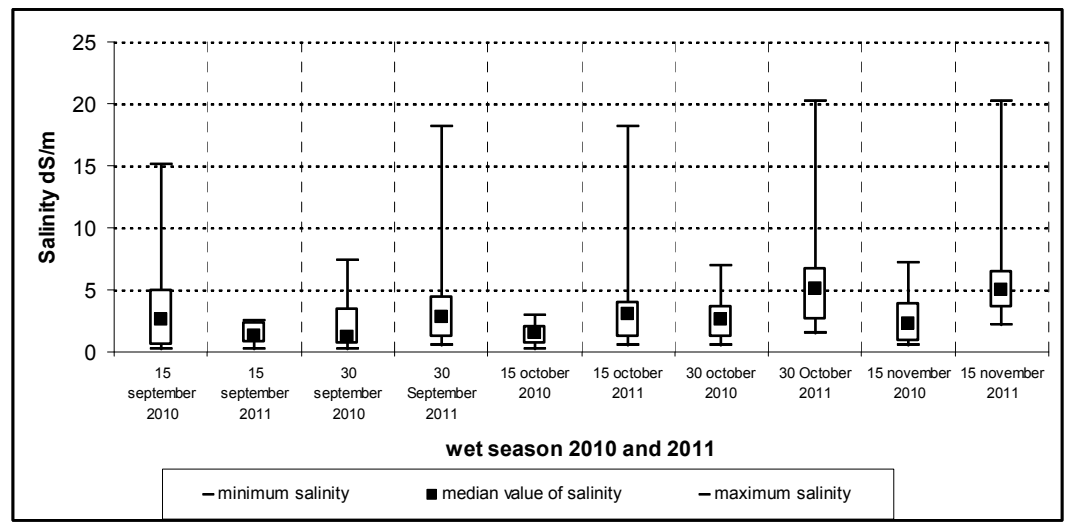

Figure 7. Evolution of the average salinity of the lowland of Ndour Ndour during wet seasons in 2010 and 2011

\section{Conclusion}

The early 1970s was a major shift in rainfall in the region of Sine Saloun. Our study demonstrated that the rupture occurred in 1967. This reinforces all the studies previously carried out, in the region, which locate the breaking point starting from the 1970s. From this point, the rainfall declined, over the time, in a linear way (slope - 3.5379 on average in the region and -1.03 at the lowland Ndour Ndour), exposing these lowland to sea water intrusion, causing degradation. Especially, it is the intra-annual variability of the rainfall which is the basis of the uncertainty in the agricultural production and which makes these people more vulnerable. Indeed, in 2010, $650.50 \mathrm{~mm}$ of rain received and distributed almost uniformly have an average rice production of $2.65 \mathrm{t} /$ ha in the lowland. Unlike in 2011, in addition to the presence of drought of end of the cycle, a total rainfall of $430 \mathrm{~mm}$ dotted with sporadic drought, implying outcrop of salt, caused the burning of several plants in the lowland. The anti-salt dam will slow down the progress of seawater into the lowlands of Sine Saloun, by maintaining a quantity of standing fresh water upstream. Without the dam no production is possible on these degraded soils. This study showed that the most important determinant for agricultural redevelopment in these degraded lands is the quantity of water that passes through.

\section{Acknowledgements}

The authors wish to thank Africa-Rice Center and the Wula Naafa program of United States Agency for International Development (USAID) for funding this work. We acknowledge the role of technical staff of Wula Naafa program of USAID, Doudou Mbaye and farmers in data collection. We wish to testify our gratitude to the African Union for its subsistence allowance through its scholarship program Mwalimu Nyerere African Union Scholarship Scheme (MNAUSS).

\section{References}

[1] Malton, P.;Randolph, T. and Gule, R. (1996). "Impact of rice research in West Africa",International Conference on impact of rice research 3-5 June 1996. Bankok, Thailand IRRI pp 313-323.

[2] AfricaRice (2006) «Le système d'information sur les basfonds de l'Afrique en l'Ouest» WAIVIS. Available at http://www.warda.org/waivis (accessed 2006) 
[3] World Bank, (2010) "World Bank Climate Change Strategy for Africa Calls for Adaptation, Mitigation and Financing" availablehttp://go.worlbank.org/L47LGXV2A0

[4] Yeo, A.R. (1999) "Predicting the interactionbetween the effects of salinity and climate change on crop plants". Scientia Horticulturaevol.78 pp 159-174.

[5] Boutkhil MORSLI,B., HABI, M. and HAMOUDI, A. (2007) "Contraintes et perspectives desaménagements hydroagricoles et antiérosifs en Algérie". Actes des JSIRAUF, Hanoi, 6-9 novembre 2007

[6] Camara, M., Kebe, M., Miezan M.K. (2007) "Caractérisation agronomique, économique et biophysique du continuum bas fond : cas des complexes sahéliens et soudano - sahéliens du sine-saloum au SENEGA." Sciences \& Nature Vol. 4 No 1 pp $1-15$.

[7] Mbodj, S.(2007) " une meilleure valorisation des bas- fonds du Sine Saloum par laGIRE”. SIWI, RANDOLL, GTZ.

[8] Verheye, W.H. (1994) "Impact of climate and soil conditions on conception and implementation of irrigation schemes in the Senegal River basin"Agricultural Water Management Vol. 28 pp 73-94.

[9] Camara, M., Kebe, M., Miezan M.K. (2008) "Intensification de la riziculture de bas-fonds dans le Sine-Saloum (Sénégal) .”Cahiers Agricultures Vol. 17 pp451-455.
[10] Pettitt, A.N., 1979. A non-parametric approach to the change-point problem. Applied Statistics 28 (2), 126-135

[11] T. A. Buishard, Some methods for testing the homogeneity of rainfall records, Journal of Hydrology, 58, 1982, pp.11-27

[12] A. F. S. Lee, M.S. Heghinian, A Shift of the Mean Level in a Sequence of Independent Normal Random Variables - A Bayesian Approach, Technometrics, 19(4), 1977, pp. 503506

[13] Bodian, A., Dacosta, H. and Dezetter, A.(2011)"Caractérisation spatio-temporelle du régime pluviométrique du haut bassin du fleuve Sénégal dans un contexte de variabilité climatique"Géographie, physique et environnement, Vol. 5.pp 107-124.

[14] Manga, A., Dorego, G.S., El Hadji, B. D., Sane, T. (2009) "Predictions pluviometriques des saltiguée et pratiques paysannes en pays serere: les croyances culturelles au service de l'agriculture. " GeographiaTechnica. Numéro spécial, pp 293-298.

[15] Servaté, P. J. E., Kouamé B., Travaglio, M., Ouedraogo, M.,Boyer,J.F., Lubèsnifl, H., Fritsch, J.M., Masson,J.M., Marieu, B. (1998) "Identification, caractérisation et conséquences d'une variabilité hydrologique en Afrique de l'Ouest et Centrale. "Water Resources Variability in Africa during the $\mathrm{XX}^{\text {th }}$ Century, Abidjan 1998 Conference, Publication AISH, ${ }^{\circ}$ 252, pp. 323-337. 